\title{
Financial and investment processes in ensuring the development of marine infrastructure
}

\author{
Larysa Hryshyna ${ }^{1 *}$, Elena Pogoryelova $^{1}$, Petro Karas $^{1}$, Natalia Mihai ${ }^{1}$, and Irina \\ Khmarska $^{1}$ \\ ${ }^{1}$ Admiral Makarov National University of Shipbuilding, Prospekt Heroyiv Ukrayiny, 9, 54007, \\ Mykolayiv, Ukraine
}

\begin{abstract}
The article identifies the place and importance of financial and investment processes in ensuring the development of maritime infrastructure as a component of the maritime complex of Ukraine. The current state of maritime infrastructure and the level of its use in the transformational conditions of the domestic economy are studied. Factors influencing the functioning and development of marine infrastructure are identified. The main directions of intensification of financial and investment processes to ensure the effective functioning and development of the maritime industry and its infrastructure are identified.
\end{abstract}

\section{Introduction}

One of the strategic directions of sustainable development of Ukraine and its integration into the Euro-Atlantic space is the formation of the country as a maritime state.To implement them, it is necessary to solve a number of problems in the field of maritime activities, including: weakening the competitive position of Ukrainian seaports in the international and regional market of port services, reducing business activity in shipbuilding and ship repair, exclusion of Ukraine from transit cargo flows and loss of transit potential; inconsistency of the state of marine infrastructure with the needs of the national economy. As the experience of other countries shows, the most attractive components of the transport system are water (sea) transportation, as the most efficient way to deliver goods due to its low cost and ability to solve problems of transportation of large cargo. The current state of maritime infrastructure shows its significant moral and physical performance, and financing its renovation and development has remained an unresolved issue for many years.

\section{Literature review}

Problems of functioning of the enterprises of the sea branch, formation and development of the sea infrastructure are considered in works of domestic scientists and practitioners, among which it is necessary to note such as G. Yefimova [1], I. Irtyshcheva [2],

\footnotetext{
*Corresponding author: grishinappi@gmail.com
} 
Y. Makogon [3], N. Prykhodko [4], M. Primachev [5], V. Vinnikov [5], A. Vorobyova [6], V. Parsyak [6], M. Fateev [6]. Most of the scientific works devoted to the study of the problems of restoration and development of the maritime industry are considered in the context of recognizing Ukraine as a maritime state with a long coastline, potentially developed maritime complex in ensuring transportation of goods through domestic and transit ports. However, a number of pressing issues of financial and investment support for the development of marine infrastructure remain, which need further research.

The purpose of the article is to study the financial and investment processes as a prerequisite for ensuring the development of maritime infrastructure in modern conditions of the domestic economy.

\section{Results}

One of the important components of the formation and further development of Ukraine as a maritime state is the adoption of the Maritime Doctrine of Ukraine for the period up to 2035 (entered into force on December 18, 2018), which aims to improve the efficiency of all marine resources and successful implementation of state maritime policy. which depend on the sovereignty and territorial integrity of Ukraine, its economic and energy independence, sustainable development and integration into the Euro-Atlantic space [7].

It should be noted that as part of the maritime complex and transport system, maritime infrastructure connects all regions and continents, which is an integral part of ensuring the integrity and unity of the world economic space. Therefore, the very concept of "marine infrastructure" has a wide range of understanding and is used to describe collective engineering structures and facilities, buildings, systems and services located within the waters to ensure effective maritime business.

Maritime infrastructure includes ports, sea lanes, docks, berths, warehouses and other facilities of entities engaged in various cargo operations. The value of these objects increases in the context of globalization of economic interests and strengthening of integration processes, when maritime transport is an important factor in the formation of world economic cooperation in maritime activities. Globalization can be seen as a process of growth of the unit cost of tonnage in a single economic space. Limited resources, distribution of products and goods depends on the level of efficiency of transport opportunities. The dependence of the development of the world economy on the technical and economic level of water transport determines the task of a balanced system of formation of its production and financial results [5].

According to the results of the analytical study of the current state of use of maritime infrastructure in Ukraine, there is a low level of use of the potential of the maritime industry and its infrastructure (Table 1) [8,9]. In particular, if in 2018, compared to 2010, the freight turnover of all transport decreased by $13.7 \%$, the transportation of goods by sea has halved. Even more negative dynamics of export-import services is observed in maritime transport.

If in 2010 the share of exports of services provided by sea transport was $15.6 \%$ of their total, in 2016 they amounted to $8.0 \%$, in $2017-10.4 \%$, in $2018-8.9 \%$.

The level of capital investment directed to the development of maritime transport has a steady trend towards minimal investment. If in 2018 the total amount of capital investment in transport increased compared to the previous period by UAH 12.2 billion $(32.2 \%)$, in maritime transport, on the contrary, there is a reduction of UAH 1.1 billion (38\%).Thus, such trends in the domestic maritime sector, general unfavorable economic and political conditions cause a gradual loss of Ukraine's potential in servicing export-import maritime cargo flows, and due to the high level of wear and tear of the maritime sector accelerates the competitiveness of domestic maritime enterprises. 
Table 1. Dynamics of indicators of activity of sea and water transport of Ukraine.

\begin{tabular}{|c|c|c|c|c|c|c|c|c|c|c|}
\hline \multirow[b]{3}{*}{ Indicator } & \multicolumn{10}{|c|}{ Years } \\
\hline & \multicolumn{2}{|c|}{2010} & \multicolumn{2}{|c|}{2016} & \multicolumn{2}{|c|}{2017} & \multicolumn{2}{|c|}{2018} & \multicolumn{2}{|c|}{2019} \\
\hline & $\begin{array}{l}\vec{\Xi} \\
\bar{\Xi} \\
\text { छ }\end{array}$ & 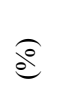 & $\begin{array}{l}\text { 志 } \\
\text { 音 }\end{array}$ & $\stackrel{\varrho}{e}$ & $\begin{array}{l}\vec{\Xi} \\
\text { 音 }\end{array}$ & $\stackrel{0}{0}$ & $\begin{array}{l}\text { 言 } \\
\text { 音 }\end{array}$ & $\stackrel{\varrho}{e}$ & \begin{tabular}{|l} 
㭉 \\
亏 \\
छ
\end{tabular} & $\stackrel{2}{2}$ \\
\hline $\begin{array}{l}\text { Freight } \\
\text { turnover, total, } \\
\text { billion.tkm, incl. } \\
\text {-maritime } \\
\text { transport } \\
\text {-river transport } \\
\end{array}$ & $\begin{array}{c}418,7 \\
3,6 \\
1,7 \\
\end{array}$ & $\begin{array}{l}100 \\
1,2 \\
0,9 \\
\end{array}$ & $\begin{array}{c}344,2 \\
2,5 \\
1,5 \\
\end{array}$ & $\begin{array}{l}100 \\
0,7 \\
0,4 \\
\end{array}$ & $\begin{array}{c}364,2 \\
2,9 \\
1,4 \\
\end{array}$ & $\begin{array}{l}100 \\
0,8 \\
0,4 \\
\end{array}$ & $\begin{array}{c}361,3 \\
1,8 \\
1,6 \\
\end{array}$ & $\begin{array}{c}100 \\
0,5 \\
0,4 \\
\end{array}$ & \begin{tabular}{|c|}
355,0 \\
1,8 \\
1,6 \\
\end{tabular} & $\begin{array}{l}100 \\
0,5 \\
0,4 \\
\end{array}$ \\
\hline $\begin{array}{l}\text { Cargo turnover } \\
\text { of maritime } \\
\text { transport by } \\
\text { types of } \\
\text { communication, } \\
\text { total, billion tkm, } \\
\text { incl. } \\
\text {-foreign } \\
\text {-shoot }\end{array}$ & $\begin{array}{l}4,92 \\
0,25\end{array}$ & $\begin{array}{c}95,2 \\
4,8\end{array}$ & $\begin{array}{l}2,22 \\
0,32\end{array}$ & $\begin{array}{l}87,4 \\
12,6\end{array}$ & $\begin{array}{l}2,38 \\
0,47\end{array}$ & $\begin{array}{l}83,5 \\
16,5\end{array}$ & $\begin{array}{l}1,58 \\
0,24\end{array}$ & $\begin{array}{l}86,8 \\
13,2\end{array}$ & $\begin{array}{l}78,0 \\
\\
22,0 \\
1,77\end{array}$ & $\begin{array}{r}100 \\
\\
1,38 \\
0,39\end{array}$ \\
\hline $\begin{array}{l}\text { Capital } \\
\text { investmens } \\
\text { billion UAH } \\
\text {-including water } \\
\text { transport }\end{array}$ & $\begin{array}{l}19,6 \\
0,18\end{array}$ & $\begin{array}{l}100 \\
0,9\end{array}$ & $\begin{array}{l}25,1 \\
0,24\end{array}$ & $\begin{array}{l}100 \\
1,0\end{array}$ & $\begin{array}{l}37,9 \\
0,25\end{array}$ & $\begin{array}{l}100 \\
0,7\end{array}$ & $\begin{array}{c}50,1 \\
0,2\end{array}$ & $\begin{array}{l}100 \\
0,4\end{array}$ & $\begin{array}{c}43,8 \\
0,3\end{array}$ & $\begin{array}{l}100 \\
0,7\end{array}$ \\
\hline $\begin{array}{l}\text { Average } \\
\text { number of full- } \\
\text { time employees, } \\
\text { thousand people } \\
\text {-including water } \\
\text { transport }\end{array}$ & $\begin{array}{c}824,3 \\
9,6\end{array}$ & $\begin{array}{l}100 \\
1,2\end{array}$ & $\begin{array}{c}659,9 \\
3,4\end{array}$ & $\begin{array}{l}100 \\
0,5\end{array}$ & $\begin{array}{c}655,2 \\
2,3\end{array}$ & $\begin{array}{l}100 \\
0,4\end{array}$ & $\begin{array}{c}648,4 \\
2,6\end{array}$ & $\begin{array}{l}100 \\
0,4\end{array}$ & \begin{tabular}{|c|}
635,1 \\
2,5 \\
\end{tabular} & $\begin{array}{l}100 \\
0,4 \\
\end{array}$ \\
\hline $\begin{array}{l}\begin{array}{l}\text { Export-import } \\
\text { of transport } \\
\text { of services, }\end{array} \\
\text { Exports, million } \\
\text { US dollars } \\
\text {-of them } \\
\text { maritime } \\
\text { transport } \\
\text { services } \\
\text { Imports, million } \\
\text { USD } \\
\text {-of them } \\
\text { maritime } \\
\text { transport } \\
\text { services }\end{array}$ & $\begin{array}{c}7835,2 \\
1 \\
234,3 \\
\\
1178,9\end{array}$ & $\begin{array}{l}100 \\
15,6 \\
100\end{array}$ & $\begin{array}{r}8300,5 \\
661,6 \\
989,2\end{array}$ & $\begin{array}{l}100 \\
8,0 \\
100\end{array}$ & $\begin{array}{r}5861,4 \\
612,1 \\
1213,1\end{array}$ & $\begin{array}{l}100 \\
10,4 \\
100\end{array}$ & $\begin{array}{r}5851,4 \\
523,3 \\
1464,8\end{array}$ & $\begin{array}{l}100 \\
8,9 \\
100\end{array}$ & $\begin{array}{r}9109,9 \\
595,5 \\
1559,1\end{array}$ & $\begin{array}{l}100 \\
5,87 \\
100\end{array}$ \\
\hline
\end{tabular}

Source: Compiled on the basis of statistical data $[8,9]$

The functioning and development of maritime infrastructure occurs under the influence of many factors that are both stimulating and deterrent or destructive (Fig. 1). In our opinion, among these factors, one of the most important should be noted financial and economic, as well as the quality of state support for the development of the maritime 
industry as a whole. Therefore, the financial and investment process should be considered the basis for the future development of maritime infrastructure, intensification of basic and applied research in domestic shipbuilding, restoring the competitive potential of the maritime transport sector of Ukraine as a whole.

Businesses operating in the seaport need to attract additional financial resources (for dredging, construction of modern shore and raid terminals, upgrade of transhipment equipment, port infrastructure) in the amount of more than 3 billion US dollars, which leads to favorable conditions for efficient investing in the economy.

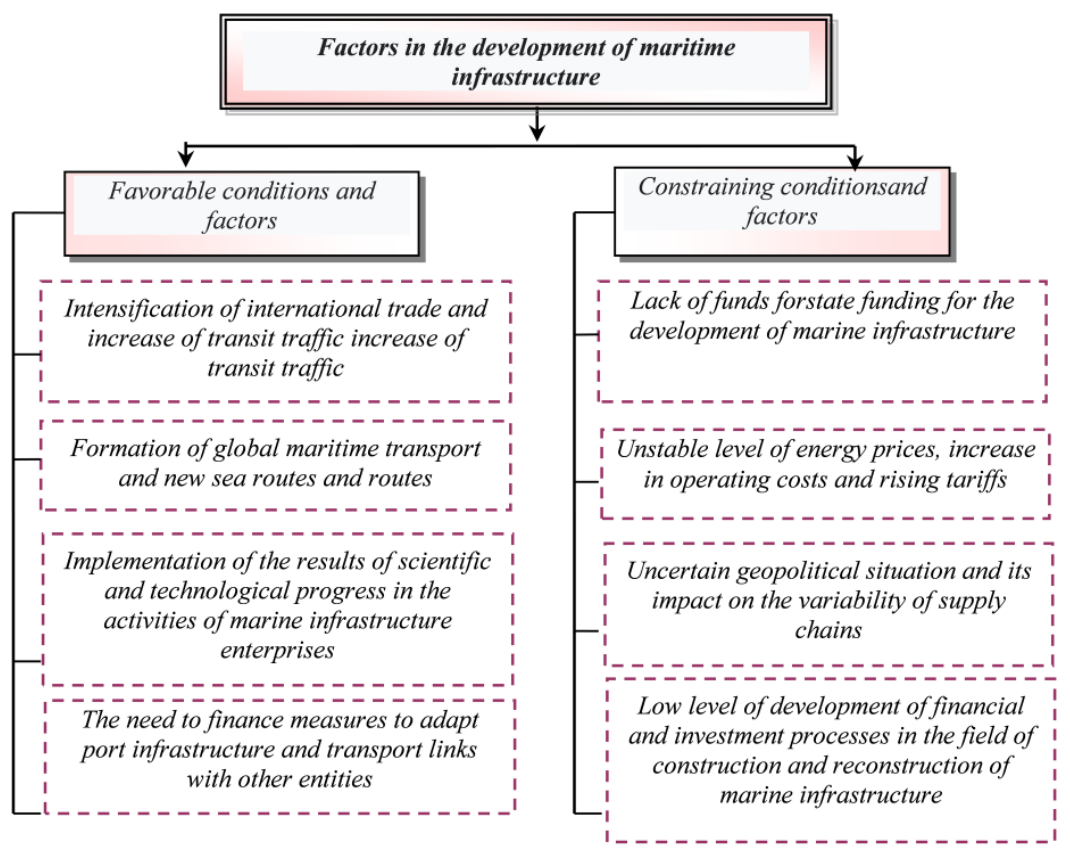

Fig.1. Factors and conditions of marine infrastructure development $[1,2,4,6]$.

According to the activities of the Administration of Sea Ports of Ukraine (AMPU), in the first half of 2019 increased capital investment in the development of port infrastructure, funding for projects to maintain passport depths in domestic ports and fleet repairs increased 1.6 times. According to the head of the AMPU, the unstable dividend policy of the state complicates the mechanism of long-term planning for the development of the port sub-sector and does not contribute to the implementation of projects for the development of maritime (port) infrastructure in the coming years.

In total, during the period of its activity AMPU has invested more than UAH 6,6 billion in the development of the port economy, and in 2020 plans to increase its profit to UAH 6,7 billion [10]. Great hopes are also placed on the activity of the Maritime Administration, the main tasks of which are: implementation of state policy in the field of sea and river transport, merchant shipping, navigation and hydrographic navigation, state control over safety, as well as formation of financing mechanism for maritime industry and its infrastructure software. But during the two years of its operation, funding issues remain unresolved, although work has been done on participation in international state donor platforms, support for the European transport program in the formation of the material and technical base of the industry.

An important event in the economic space of Ukraine was the holding in October 2019 of the First Investment Forum "RE: THINK invest in Ukraine" under the auspices of the President of Ukraine Volodymyr Zelensky [11]. 
Among the 120 investment projects should be noted 2 projects for the development of maritime infrastructure of the Black Sea region, the main indicators of which are presented in table.2.

Table 2. Business opportunities for financing investment projects for marine infrastructure development.

\begin{tabular}{|c|c|}
\hline $\begin{array}{c}\text { Specialized seaport "Olbia" } \\
\text { Business opportunity: Seaport concession }\end{array}$ & $\begin{array}{l}\text { Kherson sea trade port } \\
\text { Business opportunity: Seaport concession }\end{array}$ \\
\hline $\begin{array}{l}\text { Estimated investment amount - } \\
\$ 49 \text { million USA }\end{array}$ & $\begin{array}{l}\text { Estimated investment amount - } \\
\$ 45 \text { million USA }\end{array}$ \\
\hline $\begin{array}{l}\text { Form of ownership: Public-private } \\
\text { partnership } \\
\text { Location: Mykolayiv } \\
\text { The essence of the project: } \\
\text { - Transfer of state property to a private } \\
\text { partner-concessionaire for a period of } 35 \\
\text { years } \\
\text { - Carrying out activities in the field of } \\
\text { construction and operation of seaports } \\
\text { - A prerequisite for the project is the } \\
\text { construction by the concessionaire of a } \\
\text { grain terminal for } 2 \text { million tons per year }\end{array}$ & $\begin{array}{l}\text { Form ownership: Public-private partnership } \\
\text { Location: Kherson } \\
\text { The essence of the project: } \\
\text { - Transfer of state property to a private partner- } \\
\text { concessionaire in order to modernize the impaired } \\
\text { assets of the port } \\
\text { - Transfer of berths and in-port facilities to a } \\
\text { private investor in accordance with the concession } \\
\text { agreement } \\
\text { - Potential traffic - up to } 4 \text { million tons annually } \\
\text { until } 2030\end{array}$ \\
\hline $\begin{array}{l}\text { Area: } 145 \text { hectares } \\
\text { Existing buildings: } \\
\text { - } 6 \text { berths, } 57 \text { buildings and structures, } \\
\text { including } 2 \text { general cargo depots, } 20 \text { open } \\
\text { storages } \\
\text { Existing equipment: } \\
\text { - } 22 \text { gantry cranes, } 145 \text { units of handling } \\
\text { equipment, } 3 \text { tugs }\end{array}$ & $\begin{array}{l}\text { Area: } 195 \text { hectares } \\
\text { Term of concession: } 30 \text { years } \\
\text { Financial indicators } \\
\text { Initial investment: more than } 10 \text { million US dollars } \\
\text { Concession payments: permanent } \\
\text { ( } 340 \text { thousand US dollars) and variables (over } \\
0.73 \% \text { of annual profit) } \\
\text { Reimbursement of } 1.3 \text { million euros for the } \\
\text { development of a feasibility study }\end{array}$ \\
\hline $\begin{array}{l}\text { Implementation period: } \\
\text { depending on the business project }\end{array}$ & $\begin{array}{l}\text { Implementation period: } \\
\text { depending on the business project }\end{array}$ \\
\hline $\begin{array}{l}\text { Socio-economic effect } \\
\text { Pilot project of the concession under the } \\
\text { new transparent rules } \\
\text { Restoration of the seaport and increase of } \\
\text { grain exports } \\
\text { Increasing investment attractiveness of the } \\
\text { city of Mykolayiv }\end{array}$ & $\begin{array}{l}\text { Socio-economic effect } \\
\text { Pilot project of the concession under the new } \\
\text { transparent rules } \\
\text { Restoration of the seaport and increase of grain } \\
\text { exports } \\
\text { Increasing the investment attractiveness of the } \\
\text { Kherson region }\end{array}$ \\
\hline
\end{tabular}

Source: Compiled on the basis of data [11]

Given the current trends of the economic system of Ukraine, it is the development of maritime infrastructure will contribute to the realization of the potential of the agroindustrial complex, the scope of which covers almost three quarters of the country and generates more than $10 \%$ of GDP [8]. Compared to other industries, it is the agricultural sector that shows positive dynamics, occupies a significant share in agricultural exports and can ensure the preservation of competitive positions in the world food market.

In addition, the ongoing processes of decentralization, the creation of new communities, which received from the state more than 2 million hectares of agricultural land provide unique opportunities for the development of new technologies for production that can compete in the European and world food market. In the conditions of transformation of land 
ownership relations in Ukraine it is possible to increase long-term investments, lending to the agricultural sector of the domestic economy.

This, in turn, will contribute to the development of coastal regions, increase employment and ensure the socio-economic level of development. A positive example is the creation in the Black Sea region of production terminals for the sale of agricultural products, in particular, grain and oilseeds. Evidence of this is the activity of the company "Nibulon", which in July 2020 shipped for export on an external raid of the Mykolayiv seaport without ships in Mykolayiv 387,28 thousand tons of grain, almost 453 thousand tons of cargoes were transported by rivers (Nibulon official website). Effective foreign economic activity and a stable image of the company have made it a reliable partner for cooperation within the EU and abroad.

It is important to note that today Nibulon is one of the largest investors in Ukraine's economy - more than 2,3 billion dollars. US - and the undisputed leader in the revival of national shipbuilding - \$600 million USA [12]. In recent years, the company has headed the top 3 shipyards in the ranking of the Association of Shipbuilders of Ukraine "Ukrsudprom" as the most productive shipbuilding company[9]. Today, the shipbuilding and ship repair plant "Nibulon" is a completely modern enterprise, which is almost the only one in Ukraine that builds complete ships. It specializes in the construction of ships and vessels up to 140 meters long. The company has made a significant contribution to the reform of marine infrastructure, modernized the factory slip and embankment, renovated the crane industry, purchased the best machines and welding machines, built new shops and equipped them with state-of-the-art equipment from the world's leading manufacturers. Nibulon's fleet consists of 82 vessels for various purposes and is the newest and most modern in Ukraine. And the company's compliance with the strict requirements of international ISO standards is a confirmation of the sustainable development of the company and a significant contribution to the global market of shipbuilding and ship repair, development of marine infrastructure. One of the levers of regulation of financial and investment processes in the maritime sector is the creation of favorable investment conditions for the development of seaports and large-scale investment projects, including by improving the Laws of Ukraine "On Concessions", "On Seaports of Ukraine", "On Fisheries" , industrial fishing and protection of aquatic bioresources, adoption of the procedure and conditions for compensation of investments involved in the development of strategic objects of port infrastructure, simplification of procedures for transfer of property and land located in the port in concession; implementation of the relevant depreciation policy.

Note that in today's difficult post-crisis economic conditions (inflation, rising steel prices, lack of financial resources, rising energy prices and components) the activities of domestic shipbuilders have not yet become the key to the formation of competitive shipbuilding and ship repair as important components of Ukraine's maritime complex [4].Therefore, it is important to form and implement an effective financial and credit mechanism to support expanded reproduction in shipbuilding by providing state guarantees for loans (loans) attracted for investment projects; full or partial compensation at the expense of the state or local budgets of interest on loans obtained by business entities for the implementation of investment projects in shipbuilding; implementation of investment projects at the expense of loans (borrowings) attracted by the state on the basis of international agreements of Ukraine; state financing of leasing companies that order vessels from domestic shipbuilders.

It should be noted that an important aspect of the formation of financial and investment processes in ensuring the development of maritime infrastructure is the relationship of the maritime sector with financial institutions. 
The main requirements should be large amounts of borrowed capital, long terms and the availability of its price. The sources of such funds may be funds of legal entities and individuals, funds of public authorities, as well as the capital of banking institutions. If it is not possible to access alternative financing, then maritime infrastructure entities can use leasing services, which is quite common in developed maritime countries.

As the positive experience of other countries shows, it is advisable to create banking consortia, which are headed by a bank with sufficient liabilities, extensive lending experience and which has well-established links with financial and credit institutions. The operation of such a banking consortium can have many benefits for the development of maritime infrastructure [6].

We should not forget about the financing of innovation, the importance of which for the development of the maritime industry is difficult to overestimate. But, unfortunately, the level of financial support for the introduction of new technologies in shipbuilding, the use of innovative processes in the activities of maritime infrastructure remains low. It is the lack of equity in the enterprises of the maritime industry, which is the main source of costs for innovation, is the main reason for the low innovative level of products and services of the maritime industry [13].

For the adoption of scientifically grounded decisions on the directions of activation of financial and investment processes to ensure the effective functioning and development of the marine industry and its infrastructure it is advisable to use economic and mathematical models, which can be quantitatively described by the connection between the input parameters of the economic system and the productive indicator. In this study, a method of correlation-regression analysis is used, which includes the determination of the object sunder investigation, analysis of interconnections between individual variables, the choice of rational type of econometric model.

To build a model for the formation of strategic directions of financial and investment processes in ensuring the development of marine infrastructure, data are formed in the form of a spatial and time sampling. In particular, these data are determined as a result of the examination of the main indicators of the marine industry for 2010-2019 using the system of indicators: volumes of transported cargoes in the marine industry (X1), exports of maritime transport services (X2), import of maritime transport services (X3). In order to find out the impact of each of them, the econometric model between the misbuilt on the volume of financing of marine infrastructure:

$$
Y=f(X 1 ; X 2 ; X 3 ; u)
$$

where $\mathrm{u}-$ is a stochastic component of the model.

Based on empirical data, the values of regression coefficients were evaluated, which enabled to choose a linear model presented by such a function:

$$
\hat{y}=-261,81+0,2075 X 1+0,5032 X 2+1,3314 X 3
$$

It is worth noting that the calculated values of the determination coefficient $R^{2}=0,858$, Fischer's criterion $F_{\text {розр }}=7,18\left(\mathrm{~F}_{\text {табл }}=2,69\right)$ and the adjusted coefficient of 0,743 indicates a sufficient compliance with the empirical data of the proposed econometric model. Thus, this confirms the expediency of using the proposed model in the formation of strategic directions of intensification of financial and investment support for the development of marine infrastructure.

Regarding the financing of maritime infrastructure development through investments of foreign capital, it should be noted that they can be carried out in various forms, and the most common form is investment in share capital of enterprises, government and corporate securities. 
One of the largest partners in such cooperation is the European Bank for Reconstruction and Development (EBRD), which provides international loans on concessional terms under state guarantees and lends to private enterprises on commercial terms. Among the goals and areas of financial support are measures to complete the modernization of the main transport corridor connecting Ukraine with the European Union; project initiatives in seaports, private terminals and infrastructure. As of October 1, 2020, the total amount of EBRD funding is $€ 14,739$ billion under 479 projects. 8 joint projects with the EBRD with a total loan amount of EUR 1,701.0 million are under implementation, of which only EUR 912,58 million was spent $(53,65 \%$ of the total loan amount [14]. But due to a number of global changes, political and economic events in Ukraine, the domestic maritime industry does not have to rely on the help of foreign investors, unfortunately. In particular, in the Nikolaev area, as one of the leading regions of development of sea branch, decline of investment activity is observed. However, none of these projects provides financial support for the implementation of important initiatives for the domestic economy in the development of maritime activities.

\section{Conclusions}

Modern post-crisis conditions of the domestic economy dictate the need to intensify the use of strategic resources and potential of the maritime industry and its infrastructure, which actualizes the solution of financial and investment processes in the maritime sector. Among the main areas of solving the problem of increasing financial resources in ensuring the development of the maritime industry and its infrastructure should be identified:

- revival of the competitive Ukrainian merchant fleet by providing legislative support to Ukrainian shipping companies, application of economically justified tax and customs regimes of shipping and shipbuilding, in particular tax and customs regimes;

- participation in the implementation of TRACECA projects related to transport infrastructure in the Black Sea region;

- introduction of a transparent system of financing activities for the implementation of Ukraine's international obligations in the field of merchant shipping;

- establishment of transparent and economically sound methods of calculation, procedure for collection and exclusively targeted use of port dues and improvement of tariff policy in the port industry;

- development of the internal market of shipbuilding with the use of mechanisms of public-private partnership, implementation of the state order for the production of certain types of shipbuilding products;

- development of regional investment maps of coastal regions in the areas of «marine industry» and «recreational and tourist sphere».

Thus, further intensification of financial and investment processes in ensuring the development of maritime infrastructure requires the formation of an appropriate organizational and economic mechanism, the introduction of which will enhance investment activities, optimize sources of funding for the maritime sector, innovative development of port infrastructure and more.

To intensify the investment market, the state's credit policy must also be improved. At the same time, an important task of public policy should be to create favorable conditions for intensifying long-term lending, which is especially important for the maritime industry and will be possible through measures to increase lending by commercial banks, soften interest rate policy, reorient credit resources to long-term lending, creation of special investment banks with the provision of preferential terms for lending to investment 
programs to ensure the development of maritime infrastructure and support the formation of Ukraine as a maritime state.

\section{References}

1. Yefimova, G. (2015). Scientific principles of strategy of development of shipbuilding enterprises of Ukraine. Economist, 6, 17-24.

2. Irtyshcheva, I., Stehnei, M., \& Gurina, O. (2018). Financial mechanism of the sociooriented economic development of the black sea region. Baltic Journal of Economic Studies, 2018, 4 (4), 202-208. https://doi.org/10.30525/2256-0742/2018-4-4-202-208

3. Makogon, Yu. (2018). External economic potential of Ukraine in the black sea region. Economic Bulletin of NTUU "KPI", (15), 114-124. https://doi.org/10.20535/23075651.15.2018.135937

4. Hryshyna, L., Karas, P., \& Prykhodko, N. (2017). Development of shipbuilding industry in the context of reforming the transport system of Ukraine. Bulletin of Transport Economics and Industry, 58, 86-96.

5. Miyusov, M., Primachev, N., \& Vinnikov, V. (2006). Strategy of positioning of national sea transport in the global transport market. Odessa: Autograph.

6. Vorobyova, I., Yefimova, G., Karas, P., Kirichenko, O., Kramarenko, O., Parsyak, V., \& Khachaturov, E. (2012). Finance of shipbuilding enterprises: monograph, Nikolaev: NUC.

7. Cabinet of Ministers of Ukraine (2018). Maritime Doctrine of Ukraine for the period up to 2035. As amended by the Resolution of the Cabinet of Ministers of Ukraine of December 18. 1108. https://zakon.rada.gov.ua

8. State Statistics Service of Ukraine (2020). http://www.ukrstat.gov.ua

9. State Statistics Service of Ukraine, (2019). Transport and Communications of Ukraine 2019. http://www.ukrstat.gov.ua

10. Seaports Administration of Ukraine (2020). http://www.uspa.gov.ua

11. European Union's EU4Business Initiative (n.d.). RE: think. Invest in Ukraine. The first investment forum in Ukraine. https://eu4business.eu/uk/events/mizhnarodnyyinvestyciynyy-forum-rethink-invest-ukraine

12. Nibulon (n.d.). https://www.nibulon.com/

13. Association of Shipbuilders of Ukraine (n.d.).. http:// www.ukrsudo.kiev.ua

14. Ministry of Finance of Ukraine (2020). International cooperation: EBRD. https://www.minfin.gov.ua 